\title{
HUBUNGAN KEPATUHAN MINUM OBAT ANTIRETROVIRAL PASCA 6-12 BULAN DENGAN KADAR CD4 PADA LELAKI SEKS LELAKI (LSL) YANG TERINFEKSI HUMAN IMMUNODEFICIENCY VIRUS (HIV) DI BANDAR LAMPUNG TAHUN 2019
}

\author{
Marisa Anggraini' ${ }^{1}$, Firhat Esfandiari' ${ }^{2}$, Muhamad Rizky Arahman ${ }^{3}$ \\ ${ }^{1}$ Departemen IImu Kedokteran Komunitas Fakultas Kedokteran Universitas \\ Malahayati \\ 2Departemen Penyakit Dalam Fakultas Kedokteran Universitas Malahayati \\ ${ }^{3}$ Program Studi Kedokteran Fakultas Kedokteran Universitas Malahayati
}

[email korespondensi: muhamadrizkyarahman16@gmail.com]

\begin{abstract}
Relation of Medication Adherence Antiretroviral therapyPost 6-12 Months With CD4 Levels In Men Who Have Sex With Men (MSM) Infected Human Immunodeficiency Virus (HIV) in Bandar Lampung 2019. Human Immunodeficiency Virus(HIV) is a virus that infects cells of the immune system. To suppress the amount of virus in the blood should start antiretroviral treatment therapy. Men Who Have Sex With Men (MSM) is the highest risk factor in HIV transmission and one way to find out the immunological criteria a person infected with HIV is to measure the levels of CD4 after 6-12 months post treatment. The purpose of this study is determine the correlation of medication adherence antiretroviralafter 6-12 months with levels of CD4 . Men Who Have Sex With Men (MSM) infected Human Immunodeficiency Virus(HIV) in Bandar Lampung. This type of quantitative research with design analytic observational. Sampling using snowball sampling. Retrieving data using standard questionnaires Morisky Medication Adherence Scale (MMAS-8). The bivariate analysis using Chi Square test. Total population of the whole Men Who Have Sex With Men Men (MSM) infected with HIV in Bandar Lampung with a sample obtained 37 respondents. Univariate antiretroviral medication adherence rate of non-compliant category as many 19 people and as many 18 people obedient category. Results of bivariate test $p$ value $=0.001$. There is a significant association between antiretroviral medication adherence levels of CD4 on Men Who Have Sex With Men (MSM) infected with Human ImmunodeficiencyVirus (HIV).
\end{abstract}

Keywords: Medication adherence, Antiretroviral, CD4

\begin{abstract}
Abstrak: Hubungan Kepatuhan Minum Obat AntiretroviralPasca 6-12 Bulan Dengan Kadar CD4Pada Lelaki Seks Lelaki (LSL) Yang Terinfeksi Human Immunodeficiency Virus (HIV) Di Bandar Lampung Tahun 2019. Human Immunodeficiency Virus (HIV) adalah virus yang menginfeksi sel-sel sistem kekebalan tubuh. Untuk menekan jumlah virus dalam darah maka harus memulai terapi pengobatan antiretroviral. Lelaki Seks Lelaki (LSL) merupakan faktor risiko tertinggi dalam penularan HIV dan salah satu cara untuk mengetahui kriteria imunologis seseorang terinfeksi HIV adalah dengan mengukur kadar CD4 setelah pengobatan pasca 6-12 bulan. Tujuan penelitian ini adalah mengetahui hubungan kepatuhan minum obat antiretroviralpasca 6-12 bulan dengan kadar CD4pada Lelaki Seks Lelaki (LSL) yang terinfeksi Human Immunodeficiency Virus (HIV) di Bandar Lampung. Jenis penelitian ini adalah kuantitatif dengan desain penelitian analitik observasional dengan pengambilan sampel menggunakan snowball sampling. Pengambilan data menggunakan kuesioner baku Morisky Medication Adherence Scale (MMAS-8). Analisis bivariat menggunakan uji Chi Square.Jumlah populasi merupakan seluruh Lelaki Seks Lelaki (LSL) yang terinfeksi HIV di Bandar
\end{abstract}


Lampung dengan sampel didapatkan 37 responden. Uji univariat tingkat kepatuhan minum obat antiretroviral kategori tidak patuh sebanyak 19 orang dan kategori patuh sebanyak 18 orang. Hasil uji bivariat didapatkan nilai $p$ value $=0,001$. Terdapat hubungan bermakna antara kepatuhan minum obat antiretroviral dengan kadar CD4pada Lelaki Seks Lelaki (LSL) yang terinfeksi Human Immunodeficiency Virus (HIV).

Kata Kunci: Kepatuhan minum obat, Antiretroviral, CD4

\section{PENDAHULUAN}

Human Immunodeficiency
Virus(HIV) adalah virus yang
menginfeksi sel-sel sistem kekebalan
tubuh, menghancurkan atau merusak
fungsi sistem kekebalan tubuh, dimana
virus ini menyerang sel CD4. Infeksi
HIV membuat kerusakan progresif
sistem kekebalan tubuh, sehingga
dapat menyebabkan Acquired
Immunodeficiency Sindrome (AIDS).
Human Immunodeficiency Virus(HIV)
saat ini merupakan salah satu virus
penyebab penyakit berbahaya dan
harus diwaspadai di mana
penyebarannya sangat cepat ke
seluruh dunia (WHO, 2019).

Menurut data WHO, diperkirakan 37,9 juta orang di dunia hidup dengan HIV. Prevalensi global meningkat sejak tahun 2013 sampai 2018. Selama enam tahun terakhir, prevalensi HIV/AIDS telah menurun di negaranegara maju daripada di negara-negara berkembang. Jumlah infeksi baru pada kelompok berisiko seperti Lelaki Seks Lelaki (LSL) menjadi kelompok yang berisiko lebih tinggi terinfeksi virus HIV (WHO, 2019).

Secara global diperkirakan terdapat beberapa negara maju seperti Australia, Perancis, Inggris, dan Amerika Serikat terjadi penurunan hidup dengan HIV, kecuali dalam kelompok berisiko seperti Lelaki Seks Lelaki (LSL), di mana kelompok ini berkembang di era antiretroviral(ARV). Di Amerika Serikat, infeksi HIV pada LSL meningkat sekitar $8 \%$ pertahun sejak tahun 2001. Dan di sebagian besar Afrika, Asia, dan Amerika Latin, tingkat tertinggi infeksi HIV pada kelompok berisiko yaitu LSL. Hal ini mencerminkan peningkatan penyebaran HIV pada kelompok LSL terdapat di berbagai negara maju dan negara berkembang. (Beyrer et al, 2012).

Menurut laporan Ditjen PP \& PL Kemenkes RI pada tahun 2019, di Indonesia jumlah ODHA yang sedang mendapatkan pengobatan ARV sampai dengan bulan Juni 2019 sebanyak 115.750 orang. Walaupun ini menunjukkan kemajuan yang pesat, namun masih banyak yang putus obat sehingga membahayakan hidupnya. Menurut laporan tersebut, sebanyak 111.648 orang menerima ARV, sementara angka putus obat ARV pada ODHA masih tinggi sebanyak 55.508 orang. Laporan bulanan Provinsi Lampung pada tahun 2016 kunjungan layanan HIV sebanyak 2.328 orang, di mana 87 orang merupakan Lelaki Seks Lelaki (LSL). Dari jumlah kunjungan tersebut terdapat 1.406 orang yang terdiagnosis HIV dan 70 orang kasus HIV terjadi pada LSL (Aryastuti, 2017).

Penelitian kualitatif di Amerika Serikat yang dilakukan pada 31 homoseksual muda berkulit hitam, stigma terhadap HIV dan pemikiran negatif mengenai homoseksual pada lingkungan masyarakat menyebabkan rendahnya kepatuhan pasien dalam menjalani pengobatan antireroviral (Arnold et al, 2014). Sampai saat ini HIV/AIDS belum dapat disembuhkan, namun masih dapat dikendalikan dengan pemberian obat antiretroviral pada pasien HIV positif yang dapat memperpanjang umur harapan hidup seseorang yang terinfeksi HIV. ARV bekerja melawan infeksi dengan cara memperlambat progresifitas virus dalam tubuh. Pada dasarnya ARV bukan untuk mematikan virus, tetapi untuk memperpanjang hidup ODHA, membuat mereka lebih sehat, dan lebih produktif dengan 
mengurangi jumlah virus dalam darah dan meningkatkan jumlah sel CD4 (Green, 2016).

Salah satu cara untuk mendiagnosis HIV adalah dengan mengukur kadar CD4 (Green, 2016). Hal ini dikarenakan CD4 merupakan parameter terbaik untuk menentukan seberapa baik sistem kekebalan tubuh bekerja pada orang yang telah didiagnosis dengan HIV. Jika digunakan bersamaan dengan penilaian klinis, CD4 dapat menjadi petunjuk dini progresivitas penyakit karena jumlah CD4 menurun lebih dahulu dibandingkan kondisi klinis. Jumlah CD4 dapat berfluktuasi menurut individu dan penyakit yang dideritanya. Nilai normal CD4 sekitar 500-1.500 $\mathrm{sel} / \mathrm{mm}^{3} \quad$ (WHO, 2016). Apabila jumlahnya menurun drastis akan menyebabkan sistem kekebalan tubuh sangat rendah, sehingga memungkinkan berkembangnya infeksi oportunistik. Klasifikasi tentang imunodefisiensi primer pada orang dewasa yang terinfeksi HIV memiliki jumlah CD4nya 350-499 $\mathrm{sel} / \mathrm{mm}^{3}$ (Kemenkes, 2015).

Menurut Pedoman Nasional Terapi ARV Pada Orang Dewasa Tahun 2011 indikasi menggunakan ARV apabila kadar CD4 $<350 \mathrm{sel} / \mathrm{mm}^{3}$ tanpa memandang stadium klinisnya agar pasien memenuhi syarat untuk terapi antiretroviral dan menentukan infeksi oportunistik yang pernah dan sedang terjadi serta menentukan panduan obat yang sesuai (Kemenkes RI, 2011). Untuk mendapatkan rispon penekanan jumlah virus diperlukan tingkat kepatuhan penggunaan obat antiretroviral sebanyak 90-95\% (Kemenkes, 2015).

Masih tingginya angka putus obat atau ketidakpatuhan menjalani pengobatan ARV, maka sangat lah penting mengetahui faktor-faktor apa yang mempengaruhi kepatuhan dan ketidakpatuhan menjalani pengobatan ARV. Melihat fenomena yang ada, dapat dikatakan kepatuhan dalam pengobatan terapi antiretroviral (ARV) membantu menghambat proses perkembangbiakan HIV dalam sel CD4.
Akibatnya sistem kekebalan tubuh dilindungi dari kerusakan dan mulai pulih kembali, seperti ditunjukkan oleh peningkatan dalam jumlah sel CD4. Antiretroviral tidak membunuh virus, namun hanya dapat memperlambat laju pertumbuhan virus HIV tersebut. Obat ARV membantu menghambat proses perkembangbiakan HIV dalam sel CD4 (Green, 2016). Dengan demikian kepatuhan dalam pengobatan ARV dapat meningkatkan kadar CD4 dan memperpanjang umur harapan hidup seseorang yang terinfeksi HIV khususnya kelompok berisiko seperti Lelaki Seks Lelaki (LSL).

\section{METODE}

Jenis penelitian yang digunakan dalam penelitian ini adalah analitik observasional dengan pendekatan crosssectional. Tujuannya adalah untuk mengetahui hubungan kepatuhan minum obat antiretroviral pasca 6-12 bulan dengan kadar CD4 pada Lelaki Seks Lelaki (LSL) yang terinfeksi Human Immunodeficiency Virus (HIV) di Bandar Lampung tahun 2019.

Populasi penelitian ini adalah seluruh responden yang terinfeksi HIV pada Lelaki Seks Lelaki (LSL) di Bandar Lampung dengan menggunakan teknik sampling yaitu snowball sampling dengan cara mencari informaninforman kunci yang mengetahui keberadaan kelompok berisiko tersebut seperti Kelompok Dukungan Sebaya (KDS), Pendamping Minum Obat Antiretroviral (PMO), dan petugas layanan kesehatan terkait HIV/AIDS.

Sampel penelitian ini didapatkan dengan jumlah responden sebanyak 37 orang sesuai kriteria inklusi dan pengambilan sampel dilakukan di komunitas Gaya Lentera Muda Lampung (GAYLAM). Pengumpulan data menggunakan data primer berupa kuesioner baku Morisky Medication Adherence Scale-8 (MMAS-8) dan hasil tes CD4 setelah menjalani terapi ARV 6-12 bulan. 
Berdasarkan penelitian yang dilakukan di dapatkan hasil sebagai berikut. Berdasarkan tabel karakteristik subjek penelitian di bawah menunjukkan bahwa frekuensi Lelaki Seks Lelaki (LSL) yang terinfeksi HIV berdasarkan usia didapatkan kelompok usia termuda 20-27 tahun sebanyak 24 orang dengan persentase $(64,9 \%)$, kelompok usia 28-35 tahun sebanyak 7 orang tahun dengan persentase $(18,9 \%)$ kemudian kelompok usia $>36$ tahun sebanyak 6 orang dengan persentase $(16,2 \%)$. Distribusi frekuensi karakteristik responden berdasarkan pendidikan terakhir Lelaki Seks Lelaki (LSL) yang Terinfeksi HIV di Bandar Lampung Tahun 2019, menunjukkan bahwa responden dengan pendidikan terakhir SMA sebanyak 25 orang $(67,6 \%)$, pendidikan terakhir SMP sebanyak 6 orang $(16,2 \%)$, pendidikan terakhir perguruan tinggi sebanyak 5 orang $(13,5 \%)$, yang tidak sekolah sebanyak 1 orang $(2,7 \%)$.

Karakteristik

responden

berdasarkan pekerjaan pada Lelaki Seks Lelaki (LSL) yang terinfeksi HIV di Bandar Lampung Tahun 2019, menunjukkan bahwa responden dengan pekerjaan karyawan swasta sebanyak 19 orang $(51,4 \%)$, tidak bekerja sebanyak 11 orang $(29,7 \%)$, lainnya sebanyak 6 orang $(16,2 \%)$ dan pelajar sebanyak 1 orang $(2,7 \%)$. Berdasarkan status pernikahan Lelaki Seks Lelaki (LSL) yang Terinfeksi HIV di Bandar Lampung Tahun 2019, menunjukkan bahwa sebagian besar responden yang belum menikah sebanyak 32 orang $(86,5 \%)$ dan responden yang sudah menikah sebanyak 5 orang $(13,5 \%)$.Karakteristik responden berdasarkan lama terapi Lelaki Seks Lelaki (LSL) yang terinfeksi HIV di Bandar Lampung Tahun 2019, menunjukkan bahwa responden dengan lama terapi $<3$ tahun sebanyak 18 orang $(48,6 \%)$, lama terapi dengan rentang 3-6 tahun sebanyak 16 orang $(43,2 \%)$ dan lama terapi $>6$ tahun sebanyak 3 orang $(8,1)$. Berdasarkan CD4Lelaki Seks Lelaki (LSL) yang Terinfeksi HIV di Bandar Lampung tahun 2019, menunjukkan bahwa kelompok yang tidak naik sebanyak 20 orang dengan persentase $(54,1 \%)$ kemudian kelompok yang naik sebanyak 17 dengan persentase (45,9\%). Karakteristik responden berdasarkan kepatuhan minum obat pasca 6-12 bulan pada Lelaki Seks Lelaki (LSL) yang terinfeksi HIV di Bandar Lampung Tahun 2019, menunjukkan bahwa sebagian besar responden yang tidak patuh sebanyak 19 orang $(51,4 \%)$, dan responden yang patuh sebanyak 18 orang $(48,6 \%)$.

Tabel 1. Karakteristik Subjek Penelitian Lelaki Seks Lelaki (LSL) Yang Terinfeksi HIV di Bandar Lampung Tahun 2019

\begin{tabular}{lccc}
\hline \multicolumn{1}{c}{ Variabel } & Kategori & Frekuensi & Persentase \\
\hline \multirow{2}{*}{ Usia } & $20-27$ & 24 & 64.9 \\
& $28-35$ & 7 & 18.9 \\
& $>36$ & 6 & 16.2 \\
\hline \multirow{3}{*}{ Pendidikan Terakhir } & Tidak sekolah & 1 & 2.7 \\
& SMP & 6 & 16.2 \\
& SMA & 25 & 67.6 \\
& Perguruan tinggi & 5 & 13.5 \\
\hline \multirow{3}{*}{ Pekerjaan } & Tidak bekerja & 11 & 29.7 \\
& Pelajar & 1 & 2.7 \\
& Karyawan swasta & 19 & 51.4 \\
\multirow{2}{*}{ Status Pernikahan } & Lainnya & 6 & 16.2 \\
\hline \multirow{2}{*}{ Lama Terapi (tahun) } & Belum menikah & 32 & 86.5 \\
& Menikah & 5 & 13.5 \\
\hline
\end{tabular}




\begin{tabular}{lccc}
\cline { 1 - 3 } CD4 & $>6$ & 3 & 8.1 \\
\hline Kepatuhan & Naik & 17 & 45.9 \\
Minum Obat & Turun & 20 & 54.1 \\
\hline
\end{tabular}

Berdasarkan tabel 2. diketahui bahwa terdapat proporsi tertinggi responden menjawab kuisioner kepatuhan minum obat antiretroviral berdasarkan kuisoner Morisky Medication Adherence Scale (MMAS) didapatkan pada item kuisioner nomor 3 yaitu responden berhenti minum obat ARV karna ada efek samping sebesar $(91,9 \%)$ diikuti dengan proporsi tertinggi kedua pada item nomor 2 yaitu responden lupa minum obat ARV dalam 2 minggu terakhir sebesar $(89,2 \%)$, dan proporsi tertinggi ketiga pada item nomor 7 yaitu responden merasa tidak nyaman dalam minum obat ARV sebesar $(86,5 \%)$. Ketiga item pertanyaan di atas merupakan pertanyaan yang paling banyak di jawab oleh responden, Melihat masih tingginya ketidakpatuhan pada kelompok berisiko Lelaki Seks Lelaki (LSL) di Bandar Lampung menjadikan kepatuhan merupakan salah satu indikator keberhasilan terapi antiretroviral untuk meningkatkan kadar CD4. Kepatuhan dan kesinambungan berobat lebih menitikberatkan pada peran dan kesadaran seorang pasien (bukan hanya mengikuti perintah dokter), dengan dibantu oleh dokter atau petugas kesehatan, pendamping dan ketersediaan suatu obat.

\section{Tabel 2. Indikator Kuisoner Morisky Medication Adherence Scale(MMAS-8) Pada Lelaki Seks Lelaki (LSL) Yang Terinfeksi HIV di Bandar Lampung Tahun 2019}

\begin{tabular}{cccccc}
\hline \multirow{2}{*}{ No. } & \multirow{2}{*}{ Indikator } & \multicolumn{3}{c}{ Pengetahuan } \\
\cline { 3 - 6 } & & \multicolumn{2}{c}{ Tidak } & \multicolumn{3}{c}{ Ya } \\
\cline { 3 - 6 } & & $\mathbf{N}$ & $\mathbf{\%}$ & $\mathbf{N}$ & $\mathbf{\%}$ \\
\hline 1 & Lupa minum obat ARV secara umum & 8 & 21,6 & 29 & 78,4 \\
\hline 2 & Lupa minum obat ARV dalam 2 minggu terakhir & 4 & 10,8 & 33 & 89,2 \\
\hline 3 & Berhenti minum obat ARV karena ada efek samping & 3 & 8,1 & 34 & 91,9 \\
\hline 4 & Lupa membawa obat ARV saat berpergian & 8 & 21,6 & 29 & 78,4 \\
\hline 5 & Lupa minum obat ARV 1 hari terakhir & 9 & 24,3 & 28 & 75,7 \\
\hline 6 & Berhenti minum obat ARV karena merasa sehat & 6 & 16,2 & 31 & 83,8 \\
\hline 7 & Merasa tidak nyaman dalam minum obat ARV & 5 & 13,5 & 32 & 86,5 \\
\hline 8 & Kesulitan mengingat waktu minum obat ARV & 7 & 18,9 & 30 & 81,1 \\
\hline & Rata-rata & $\mathbf{6}$ & $\mathbf{1 6 , 8}$ & $\mathbf{3 1}$ & $\mathbf{8 3 , 1}$ \\
\hline
\end{tabular}

Berdasarkan hasil analisis uji bivariat data pada tabel 3 . Hubungan Kepatuhan Minum Obat Antiretroviral Pasca 6-12 Bulan Dengan Kadar CD4Pada Lelaki Seks Lelaki (LSL) yang Terinfeksi Human Immunodeficiency Virus (HIV) di Bandar Lampung Tahun 2019, diperoleh bahwa dari 37 responden terdapat 16 orang tidak patuh dengan kadar CD4 tidak naik $(84,2 \%)$ dan 3 orang tidak patuh CD4 naik $(15,8 \%)$ sementara responden patuh terdapat 4 orang dengan kadar
CD4 tidak naik $(22,2 \%)$ dan 14 orang patuh dengan CD4 naik (77,8\%). Hasil uji statistik diperoleh nilai $p$ value $=0,001$ maka dapat disimpulkan terdapat hubungan yang bermakna antara kepatuhan minum obat antiretroviral pasca 6-12 bulan dengan kadar CD4. Dari hasil analisis diperoleh nilai oddsratio $=18,67, \quad$ artinya responden dengan kepatuhan minum obat patuh memiliki peluang $18,67 \mathrm{kali}$ CD4 akan naik. 

Tabel 3. Hubungan Kepatuhan Minum Obat ARV Pasca 6-12 Bulan Dengan Kadar CD4 Pada Lelaki Seks Lelaki (LSL) Yang Terinfeksi HIV di Bandar Lampung Tahun 2019

\begin{tabular}{|c|c|c|c|c|c|c|c|c|c|}
\hline \multirow{3}{*}{ Kepatuhan } & \multicolumn{4}{|c|}{ CD4 } & \multirow{2}{*}{\multicolumn{2}{|c|}{ Total }} & \multirow{3}{*}{ OR } & \multirow{3}{*}{$\stackrel{P}{\text { value }}$} & \multirow{3}{*}{$\begin{array}{c}\text { CI } \\
(95 \%)\end{array}$} \\
\hline & \multicolumn{2}{|c|}{ Tidak Naik } & \multicolumn{2}{|c|}{ Naik } & & & & & \\
\hline & $\mathbf{N}$ & $\%$ & $\mathbf{n}$ & $\%$ & $n$ & $\%$ & & & \\
\hline Tidak Patuh & 16 & $84.2 \%$ & 3 & $15.8 \%$ & 19 & $100.0 \%$ & \multirow{3}{*}{18.67} & \multirow{3}{*}{0.001} & \multirow{3}{*}{$\begin{array}{l}3.55- \\
98.16\end{array}$} \\
\hline Patuh & 4 & $22.2 \%$ & 14 & $77.8 \%$ & 18 & $100.0 \%$ & & & \\
\hline Total & 20 & $54.1 \%$ & 17 & $45.9 \%$ & 37 & $100.0 \%$ & & & \\
\hline
\end{tabular}

\section{PEMBAHASAN}

Kepatuhan atau adherence pada terapi adalah sesuatu keadaandimana pasien mematuhi pengobatannya atas dasar kesadaransendiri sehingga mencapai supresi virologis yang baik dan optimal, setidaknya $95 \%$ darisemua dosis tidak boleh terlupakan (Kemenkes RI, 2011).Kegagalan terapi ARV sering diakibatkanoleh ketidakpatuhan pasien dalam mengkonsumsi ARV yang akan menyebabkan virus resisten dan bereplikasi sehingga menyebabkan munculnya infeksi-infeksi baru (Green, 2016).

Kriteria gagal terapi ARV menurut WHO ditentukan berdasarkan 3 kriteria yaitu kriteria klinis, imunologis, dan virologis (WHO, 2007). Dalam penelitian ini di dapatkan hasil ketidakpatuhan dalam mengonsumsi ARV dengan kadar CD4 tidak naik sebesar $(84,2 \%)$. Pada penelitian lain di Rumah Sakit Rujukan Universitas Gondar, Ethiopia Barat Laut yang menunjukan bahwa terdapat peningkatan kadar CD4 pada seseorang yang patuh dalam mengkonsumsi antiretroviral (Molla et al, 2018). Penelitian ini juga diperkuat oleh Maharharsta di India pada tahun 2012 menunjukan adanya peningkatan pada rata rata kadar CD4 dari awal yaitu $222 \mathrm{sel} / \mathrm{mm}^{3}$ menjadi 306 $\mathrm{sel} / \mathrm{mm}^{3}$ setelah menjalani terapi menggunakan ARV selama 6-12 bulan. Beberapa penelitian tersebut juga selaras dengan apa yang telah ditetapkan Kementrian Kesehatan RI melalui Buku Pedoman Nasional Tatalaksana Klinis Infeksi HIV dan Terapi Antiretroviral Pada Orang Dewasa yaitu ketika seorang memulai terapi antiretroviral pada CD4 $<350$ $\mathrm{sel} / \mathrm{mm}^{3}$ maka akan terjadi peningkatan kadar CD4 setelah pemberian antiretroviral antara 50-100 $\mathrm{sel} / \mathrm{mm}^{3} /$ tahun (Kemenkes RI, 2011).

Beberapa faktor yang menyebabkan responden penelitian tidak patuh dalam mengonsumsi obat ARV berdasarkan jawaban kuisoner penelitian ini sebesar $(91,9 \%)$ dikarenakan responden memiliki efek samping ketika mengonsumsi obat ARV diikuti dengan jawaban responden yaitu dalam 2 minggu terakhir terdapat hari dimana responden lupa mengonsumi obat ARV sebesar $(89,2 \%)$ dan jawaban merasa tidak nyaman dalam minum obat ARV sebesar (86,5\%). Hasil penelitian Anwar dkk (2018) yang berjudul Profil Efek samping Antiretrovirus Pada Pasien HIV/AIDS di RSPI Prof. Dr. Sulianti Saroso Jakarta pada 95 pasien mengalami efek samping ringan dan berat yaitu sakit kepala, alergi, mual/muntah, sulit tidur dan efek samping berat adalah anemia.

Sebagian besar kelompok beresiko seperti Lelaki Seks Lelaki (LSL) yang terinfeksi HIV di Bandar Lampung yang menjalani terapi antiretroviral masih banyak yang tidak 
patuh dalam mengonsumsi ARV. Peran kelompok dukungan sebaya di dalam sistem penanggulangan HIV di tingkat Provinsi dan Kota/Kabupaten dapat terus berlanjut dan berperan dalam sistem penanggulangan HIV/AIDS jika faktor-faktor yang berhubungan dengan keberlanjutan kelompok dapat terus berkembang. Peran kelompok dukungan sebaya (KDS) membantu manajer kasus dalam pemantauan minum obat dan evaluasi, serta merawat ODHA jika sakit, karena kemungkinan keluarga tidak mau merawat. Selain itu menjembatani kebutuhan pada layanan VCT. Maka dibutuhkan peran KDS, untuk memberikan dukungan dalam kehidupan sehari-hari agar mempengaruhi kepatuhan ODHA dalam mengkonsumsi ARV (Handayani dan Mardhiati, 2018).

\section{KESIMPULAN}

Peningkatan kadar CD4 50-100 $\mathrm{sel} / \mathrm{mm}^{3} /$ tahun pasca $6-12$ bulan menjalani terapi ARV merupakan indikator keberhasilan kriteria imunologis pada seseorang yang positif HIV yang mendapat terapi ARV lini pertama dengan kepatuhan minum obat $>95 \%$ dengan baik.Pada penelitian ini diketahui terdapat hubungan yang bermakna antara kepatuhan minum obat antiretroviralpasca $6-12$ bulan dengan kadar CD4pada Lelaki Seks Lelaki (LSL) yang terinfeksi Human Immunodeficiency Virus (HIV) di Bandar Lampung tahun 2019, dengan diperoleh pvalue $=0,001$ ( $p$ value $<0,05)$. Studi lain dengan ukuran sampel yang lebih besar, kriteria subjek yang lebih baik, dan bersifat multisenter perlu dilakukan di Indonesia untuk memperkuat hasil penelitian ini.

\section{SARAN}

Bagi individu yang menjalani terapi ARV diharapkan untuk meningkatkan kepatuhan minum obat ARV agar tidak terjadi kegagalan pengobatan terutama resistensi obat ARV di masa mendatang serta untuk individu diharapkan terlibat dalam layanan pendorong kepatuhan ARV melalui platform Whatsapp yang berisikan tenaga layanan kesehatan seperti dokter, perawat, psikolog, pendamping minum obat (PMO) untuk memberikan motivasi dan membantu meningkatkan kepatuhan minum obat ARV serta memperpanjang harapan hidup ODHA.

\section{DAFTAR PUSTAKA}

Anwar, Y., Nugroho, S. A., \& Tantri, N. D. (2018). Karakteristik sosiodemografi, klinis, dan pola terapi antiretroviral pasien HIV/AIDS di RSPI Prof. Dr. Sulianti Saroso periode JanuariJuni 2016. Jurnal Farmasi Indonesia (Pharmaceutical Journal of Indonesia) 15(1): 7289.

Arnold, E. A., Rebchook, G. M., \& Kegeles, S. M. (2014). Triply cursed: racism, homophobia and HIV-related stigma are barriers to regular HIV testing, treatment adherence and disclosure among young Black gay men. Culture, health \& sexuality 16(6): 710722.

Aryastuti, N. (2017). Perilaku Pencarian Pelayanan Kesehatan Pada Gay Yang Terinfeksi Human Immunodeficiency Virus (HIV) Di Bandar Lampung. Jurnal Dunia Kesmas, 6(3).

Beyrer, C., Baral, S. D., Van Griensven, F., Goodreau, S. M., Chariyalertsak, S., Wirtz, A. L., et al. (2012). Global epidemiology of HIV infection in men who have sex with men. The Lancet, 380(9839): 367-377.

Ditjen PP \& PL Kemenkes RI. 2019.Laporan Direktorat Jendral Pencegahan dan Pengendalian Penyakit Infeksi Menular Seksuak Triwulan II Tahun 2019. Jakarta: Kementerian Kesehatan RI. 
Green, C. (2016). Pengobatan Untuk AIDS. Jakarta: Spiritia.

Handayani, S., \& Mardhiati, R. (2018). Keberlanjutan Peran Dukungan Sebaya di Dalam Sistem Penanggulangan HIV di Tingkat Provinsi dan Kota/Kabupaten Indonesia. Jurnal Perilaku dan Promosi Kesehatan, 1(1): 4453.

Kemenkes RI. (2011). Pedoman Nasional Tatalaksana Klinis Infeksi HIV dan Terapi Antiretroviral Pada Orang Dewasa. Jakarta: Direktorat Jenderal Pengendalian dan Penyehatan Lingkungan.

Kemenkes RI. (2015). Pedoman pelaksanaan pencegahan penularan HIV dan sifilis dari ibu ke anak bagi tenaga kesehatan. Jakarta: Pusat Data dan Informasi Kementrian Kesehatan RI.

Molla, A. A., Gelagay, A. A., Mekonnen, H. S., \& Teshome, D.
F. (2018). Adherence to antiretroviral therapy and associated factors among HIV positive adults attending care and treatment in University of Gondar Referral Hospital, Northwest Ethiopia. BMC infectious diseases, 18(1): 266.

WHO (World Health Organization). (2007). Who case definitions of HIV for surveillance and revised clinical staging and immunological classification of HIV-related disease in adults and children. Geneva: WHO.

WHO (World Health Organization). (2016). Consolidated guideline on the use of antiretroviral drugs for treating and preventing HIV infection $\left(2^{\text {nd }}\right.$ ed). Geneva: WHO.

WHO (World Health Organization). (2019). HIV/AIDS. [Diakses dari www.who.int/news-room/factsheets/detail/hiv-aids pada tanggal 16 September 2019. 